\title{
Financial Structure: A Comparative Study between European Listed and Unlisted Companies
}

\author{
Carmelo Intrisano ${ }^{1}$, Anna Paola Micheli ${ }^{1}$, Anna Maria Calce ${ }^{1}$ \\ ${ }^{1}$ University of Cassino and Southern Lazio, Cassino, Italy \\ Correspondence: Anna Maria Calce, University of Cassino and Southern Lazio, Cassino, Via Folcara snc, Italy. \\ E-mail: annamariacalce@unicas.it, ORCID: 0000-0003-1877-9932
}

Received: September 15, 2020

Accepted: October 16, 2020

Online Published: October 21, 2020

doi:10.5539/ijbm.v15n11p111

URL: https://doi.org/10.5539/ijbm.v15n11p111

\begin{abstract}
This paper aims to ascertain whether differences exist in the composition of the financial sources in listed and unlisted companies.

In detail, we conduct a differential analysis of the financial structure, measured as debt to equity ratio (D/E), comparing European listed companies to unlisted peers. Analysis cover the period 2015-2017. The main samples of listed and unlisted companies were grouped in nine sub samples representative of as many economic sectors: Healthcare, Consumer cyclical, Consumer non-cyclical, Energy, Industrials, Basic materials, Technology, Telecommunications and Utilities. We compared the average value of debt to equity ratio for listed and unlisted companies, for different sectors in order to verify if in listed companies the incidence of debt is lower than that for unlisted ones as stated from the majority literature. Then, we calculated the differences between means as "means of $\mathrm{D} / \mathrm{E}$ for listed companies-means of $\mathrm{D} / \mathrm{E}$ for unlisted companies" and we used the $\mathrm{t}$-test to observe the statistical significance. Results showed that differences between means were significant at $1 \%$ level: so, averages D/E ratio were comparable and they appeared almost always greater for unlisted companies. This confirms that unlisted companies make greater use of debt capital.
\end{abstract}

Keywords: financial structure, debt, equity, stock listing, listed companies, unlisted companies

\section{Introduction}

Firms choose funding sources considering appropriately the advantages and disadvantages on the value maximization process, as well as the degree of consistency with financial needs in relation to the timing of the return flows underlying the assets. It is necessary to avoid that the outflows related to the remuneration and return of capital are temporally anticipated with respect to the inflows produced by the investments; in fact, if this condition is not respected the company could be unable to meet its obligations towards the lenders.

From this perspective, equity leads the advantage for the company of having capital without a specific repayment date (Ou and Haynes; 2006). Shareholders are remunerated compatibly with the cash flows produced by management and, consequently, the company can count on greater flexibility, contrary to what happens with debt which has greater rigidity.

In summary equity reduces the risk of the company, makes free cash flow to equity less uncertain and, in this way, generates value for the shareholder.

In the context of risk capital, it is necessary to choose between the contribution of the owner, self-financing and recourse to the stock market.

The first two are the most consistent methods with the maximizing shareholder value approach. This because the recourse to the stock market and the consequent issue of additional shares would cause a dilution of ownership and control. In order to maintain corporate control, the owner-managers may prefer loans in the form of debt, rather than increasing the share capital and obtaining additional resources as equity.

\section{Literature Review}

Several authors analysed financial structure decisions. With regard to debt, the choice between the short and medium-long term is influenced by the benefits and disadvantages associated with financial sources (García-Teruel \& Martínez-Solano, 2007). Short-term debt has generally lower nominal interest rates and is easily adaptable to 
the financial needs of the firm but it carries a higher level of risk (Jun \& Jen; 2003). Considered that, weak firms should prefer long-term debt since the benefits of the short term are not deemed sufficient to compensate for the additional risks (García-Teruel \& Martínez-Solano, 2007).

Beyond these general criteria which would determine the decisions on the financial structure, the choices are influenced by several variables, such as the phase of the life cycle, the size, the profitability, the availability of collateral, the ownership structure, the sector to which company belongs and the geographical location (Guiso, 2003; Worthington, 2013).

With regard to the life cycle, in the start-up phase the financial need is connected to the requirement to conceive and develop the project, build the working capital and prepare the production capacity. Investments for the development of the project (i. e. for research and development, marketing analysis and personnel selection) are in this phase of modest amount; those for the production structure (i. e. machinery, plants and equipment) are more consistent and investments for working capital are more or less significant depending on the company's operations. In this phase the economic results are negative, given sales volumes insufficient to cover fixed costs. Therefore, the company cannot count on self-financing and must cover financial needs only with external sources. Nonetheless, bank financing is often inaccessible at this stage due to negative cash flows, especially when the company does not have available assets to lend as collateral. Consequently, risk capital of external origin is the obligatory choice to start the business (Caselli, 2003). Normally, the risk capital of external origin is represented by the equity coming from the owner's assets. If this is insufficient, company must necessarily resort to the stock market. Businesses encounter similar difficulties in the development phase, in covering investment in innovation, especially when self-financing is not sufficient to cover the related financial needs. Recourse to bank credit shows also in this phase strong critical elements, due to the high risk associated with the projects to be implemented and considering the immateriality of the investments which makes their remuneration uncertain (Corigliano et al., 2001). Hence, the strong need for equity to be acquired from the stock market and to be allocated to the financing of innovation.

In subsequent years, if the company manages to achieve substantial margins, the resources generated by management and not distributed will contribute to increasing its capital endowment. Furthermore, with the consolidation of the activity, the company will have access to mercantile credit, bank credit in the various short, medium and long-term financing methods as well as leasing transactions for investments in production capacity and factoring for the disposal of working capital (Hutchinson \& Ray, 1983).

Considering the size factor, small and medium-sized enterprises encounter a constraint in the low liquidity, which forces them to resort to external sources of financing especially in the form of debt (Bates, 1967; Hutchinson \& Ray, 1983; Keown et al. 1985). However, the small size also affects its accessibility to external funding: for SMEs the external recourse to funds is more expensive and difficult as shown by various empirical evidences that highlight how small and medium-sized enterprises do not have the same financing opportunities as large companies in interfacing with the financial system (Bates \& Hally, 1982; Osteryoung et al., 1997).

So, given the unavailability of some forms of financing and considering the greater difficulties and constraints in the use of funds, SMEs can often rely only on share capital limited to the availability of the owner and selffinancing (McLaney, 2009) because reaching for resources on the stock market is difficult to access. In conclusion, SMEs suffer and do not choose the financial structure (Beck \& Demirguc-Kunt, 2006; Ayyagari, Demirkuc-Kunt \& Maksimovic, 2005; Carpenter and Peterson, 2002).

Information asymmetry is another relevant factor in firms' financial decision-making. For the majority of companies, the relationship established with the lenders is characterized by elements of information asymmetry because not all the information available to the company is shared with the lenders. The information asymmetry is at the origin of the adverse selection: in the phase preceding the negotiation of the financing, the greater availability of information by the loan applicant generates a contractual imbalance and opportunistic behaviour, distorting the information or selecting the information in order to transfer only information that is not prejudicial to one's standing to the lender. Contractual asymmetry leads to moral hazard, when the debtor, after the completion of the financing agreement, transfers to the creditor information that does not correspond to the actual business condition or to the real changes that affected the solvency of the company in the period following the negotiation.

The direct transfer of information by the borrower is influenced by its natural tendency to obscure part of the riskiness of the company in order to secure the loan or optimize the contractual conditions in its favour. On these assumptions, the lender can reduce the information asymmetry by catching some signals from the company (i. e. the desire to invest in the project or company represents confirmation of the true quality of the project).

Therefore, an inverse relationship follows between the possibility of accessing the different forms of external 
financing and the level of information asymmetry: in the extreme case of maximum information asymmetry (i.e. total unavailability of information for the lender) the company presumably cannot resort externally to find financial sources and it can rely solely on self-financing to cover its financial needs; as information becomes more available, the company is able to procure itself externally first with debt capital and then also with risk capital.

The information asymmetry therefore influences the choice of the financial structure as widely stated by the Pecking Order Theory, according to which, in the presence of an irregular distribution of information between insiders and outsiders, the use of external financing produces a signalling effect on the market (Ross, 1977; Leland \& Pyle, 1977; Myers \& Majluf, 1984). In this perspective, external lenders would not be able to determine exactly the value of the securities issued by the companies to carry out new projects and investments, so they would conclude that managers of the company decide in the interest of the current shareholders. A possible share issue would be conceived by the market as an attempt to transfer value from the new to the current shareholders, so that equity would be placed at a much lower price than the market, and in this way penalizing the wealth of the shareholders.

Hence the tendency of managers to retrograde the use of equity of external origin by giving priority to other forms of financing considered more suitable for protecting shareholder value. Preference is assigned to self-financing and debt capital is chosen only in the event of insufficient self-financing.

Even the issuance of debt securities or the use of bank debt assumes a signal value towards the market in terms of value transfer from creditors to shareholders. The indebted company tends to place additional debt at the same conditions as the previously issued debt, reducing the market value of the existing debt. On these assumptions, company can place the debt only by accepting the greater interest rates required by the lenders.

The use of additional debt can also signal a transfer of wealth from creditors to shareholders when it is intended for investments with more volatile returns than investments already made, on the basis of which, instead, the interest rate is fixed. Even in this case, the signal may induce the lender to request higher interest rates for the new issue than market rates.

A sort of hierarchy is configured in the choice of financing sources: self-financing is preferred to debt, given that resources of internal origin do not involve agency costs that can be associated with debt due to the information asymmetry between entrepreneurs and lenders (Fama \& Miller, 1972; Jensen \& Meckling, 1976). Among the external sources, debt is preferred to equity both because creditors, being able to contain information asymmetries and reduce agency costs through systematic screening and monitoring of the positions taken, are willing to accept even more contained increases on the interest rate, and because the creditors having granted the loan, indirectly send a positive signal to the market regarding the company's reputation determining an increase in value for shareholders.

The information asymmetry, therefore, is relevant in the start-up phase as it can preclude the possibility of external financing and condition the survival of the company to the financial resources of the founder or to his assets to be provided as collateral (Carpenter \& Petersen 2002; Holtz-Eakin, Rosen \& Joulfaian 1994). In growth phase of the life cycle, the information asymmetry continues to be high. Company can resort to bank credit and, for risk capital, to venture capitalists who, due to their characteristics and given the methods of intervention, are able to limit the information deficit on the target company. In the consolidation phase, the company is able to sufficiently inform the outside, its reputation grows and can directly address the securities market through the issue of bonds, the listing and placement of new shares. This is confirmed by numerous empirical evidences that have shown how debt decreases with the aging of the company, so that the longer-lived companies show a greater incidence of equity (Berger \& Udell 1998).

The information asymmetry explains, together with other factors, the differences in financial structure between SMEs and other companies, given the information opacity that characterizes them prime (Berger \& Udell, 1998). In small and medium-sized enterprises, much of the information remains internally, not requiring the constraints of auditing the financial statements nor the disclosure obligations provided for listed companies. Moreover, the confusion which usually arises between the business activity and the private sphere of the owner, drives not to share information with the outside how it happens in the family unit.

Poor disclosure transparency makes external recourse critical and conditions the choices of financial structure (Berger \& Udell, 1998).

Bank debts prevail among external sources, with a preponderance of short-term debts easier to monitor. Short-term debt is, in fact, an effective way to deal with asymmetric information problems as firms have to repay debt and any associated charges over a shorter period (Myers, 1977). Some studies compared the financial structure of listed 
and unlisted firms concluding that the first ones have a lower financial leverage (Rondi et al. 1994, Schoubben \& Van Hulle 2004, Capasso et al. 2005, Brav 2009, Gao, Harford \& Li 2013, Asker, Farre-Mensa \& Ljungqvist 2014, Kopyakova 2017).

The economic trend may have repercussions on the financial structure. In 2007, for example, banks reduced their operations, granting loans on stricter terms, increasing rates or asking for more guarantees. The reasons underlying this behaviour are to be attributed to the erosion of their capital by losses due to the mortgage crisis and to worries about the solvency of customers. Credit crunch initially hit all businesses and then small and medium-sized ones. In subsequent years, the decline in loans was affected by a further contraction in the granting of credit to businesses due to the greater perceived risk, given the evolution of economic activity in general. This has also led to an increase in interest rates on loans. The contraction in bank credit has made businesses more vulnerable aggravating their risk profile. Similarly, when fears about growth and more expansive monetary policies prevailed on the market, there was a decline in long-term yields and a constriction of the propensity to invest in the stock market. This resulted in reduced accessibility to equity, more in listed than in unlisted companies, given the greater use of the market by the listed ones. In any case, the changes in the financial structure, due to the credit crunch or attributable to a negative sentiment towards equity investment, do not have the same relevance between companies and take on different intensities depending on their activity.

\section{Methodology}

This work consists in the differential analysis of the financial structure by listed companies compared to unlisted ones. The methodological approach is common with other empirical evidence, from which, however, it differs, and hence the innovativeness of this evidence, since it isolates the variations recorded over time from the D/E ratio and attributable to the sector to which it belongs, using distinct survey samples for the different sectors.

The ratio is used to evaluate a company's financial leverage. The $\mathrm{D} / \mathrm{E}$ ratio is an important metric used in corporate finance. It is a measure of the degree to which a company is financing its operations through debt versus whollyowned funds. More specifically, it reflects the ability of shareholder equity to cover all outstanding debts in the event of a business downturn. In general, a company with a high $\mathrm{D} / \mathrm{E}$ ratio is considered a higher risk to lenders and investors because it suggests that the company is financing a significant amount of its potential growth through borrowing. What is considered a high ratio can depend on a variety of factors, including the company's industry.

Industries, in fact, are affected and react in different ways to the economic situation: cyclical firms amplify market trends while non-cyclical firms show greater stability over time. It follows that the surveyed companies could show a differential value, since they belong to two different sectors and not because of their listed / unlisted status.

We wanted to verify if in listed companies the incidence of debt is lower than for unlisted ones as stated from the majority literature. In this study we compared two samples representative respectively of listed and unlisted companies extracted from the Amadeus database. The initial population included 861878 companies, of which 4209 listed and 857669 unlisted. Companies were grouped into nine sub-samples, corresponding to the sectors: Healthcare, Consumer cyclical, Consumer non-cyclical, Energy, Industrials, Basic materials, Technology, Telecommunications and Utilities. Furthermore, given the low number of listed companies by sector and in order to improve the significance of results, we constructed samples by selecting companies from several European countries. Assuming that sharing the equity index still implies elements of affinity between the countries themselves, countries included in the Stoxx Europe 600 Index were selected (Austria, Belgium, Czech Republic, Denmark, Finland, France, Germany, England, Ireland, Italy, Luxembourg, Holland; Norway, Portugal, Sweden, Switzerland and Spain).

The methodological approach is coherent with other empirical evidence. However, it presents some differences since it isolates the variations recorded over time attributable to the sector to which company belongs using separate survey samples for the different sectors. This because they are affected and react in different ways to the economic situation: i. e. cyclical firms amplify market trends while non-cyclical firms show greater stability over time.

Analysis cover the period 2015-2017. We computed financial structure as the debt/equity ratio (D/E). The series of $\mathrm{D} / \mathrm{E}$ were subjected to the elimination of outliers to improve the normality of distributions and their statistical significance. The final composition of the two samples was represented as follows:

- for 2015: n. 393678 companies (of which 2593 listed);

- for 2016: n. 411902 companies (of which 2694 listed);

- for 2017: n. 260178 (of which 2763 listed). 
Then, the means of D/E were calculated for each year and for each sector. We computed differences between means as "D/E for listed companies-D/E for unlisted companies": a positive difference indicates that the incidence of debt capital on equity in listed companies is higher than that found for unlisted companies and vice versa if the difference in the averages takes a negative value. We tested the statistical significance of differences between the means using the $\mathrm{t}$-test. Based on the results obtained from the statistical test, we compared financial structure for listed companies and for the unlisted peers.

\section{Differential Analysis of the Financial Structure (D/E): Results}

This survey intends to ascertain any differences recorded by the financial structure, separately by status listed/unlisted, sector and year of reference. The following table highlights the average values of D/E ratio obtained for each economic sector and for each year of analysis. As we can note, average values are almost always greater for unlisted companies that means unlisted companies make greater use of debt capital. For the Health care and the Utility sectors D/E ratio for listed companies appears higher than that obtained for unlisted ones. In detail, for Health care we observe a greater incidence of debt over the years 2016 and 2017, while for Utility the greater presence of debt is relative to the years 2015 and 2016.

Table 1. D/E (average value): listed vs unlisted companies

\begin{tabular}{lllllllll}
\hline \multirow{2}{*}{ Sector } & $\mathbf{2 0 1 5}$ & & $\mathbf{2 0 1 6}$ & & $\mathbf{2 0 1 7}$ & \multicolumn{2}{c}{$\mathbf{2 0 1 5 - 2 0 1 7}$} \\
& Listed & Unlisted & Listed & Unlisted & Listed & Unlisted & Listed & Unlisted \\
Health care & 0.96 & 0.98 & 1.00 & 0.96 & 0.93 & 0.92 & 0.96 & 0.95 \\
Consumer cyclical & 1.14 & 1.60 & 1.02 & 1.85 & 1.04 & 1.59 & 1.07 & 1.68 \\
Consumer non-cyclical & 0.91 & 1.56 & 0.93 & 1.56 & 0.88 & 1.54 & 0.91 & 1.55 \\
Energy & 2.02 & 3.12 & 1.77 & 2.86 & 1.87 & 2.67 & 1.89 & 2.88 \\
Industrial & 1.20 & 1.58 & 1.22 & 1.58 & 1.19 & 1.49 & 1.20 & 1.55 \\
Basic materials & 0.64 & 1.36 & 0.65 & 1.34 & 0.68 & 1.35 & 0.66 & 1.35 \\
Technology & 0.87 & 1.61 & 0.97 & 1.57 & 0.93 & 1.53 & 0.92 & 1.57 \\
Telecommunications & 1.52 & 1.53 & 1.34 & 1.56 & 1.33 & 1.57 & 1.40 & 1.55 \\
Utility & 1.47 & 1.34 & 1.71 & 1.55 & 1.89 & 2.22 & 1.69 & 1.70 \\
\hline
\end{tabular}

In the 2015-2017 period, the listed companies with the highest leverage values belong, in order, to the following sectors: Energy (1.89), Utility (1.69) and Telecommunications (1.40), while those with the lowest values are in the sectors Technology (0.92), Consumer non-cyclical (0.91) and Basic materials (0.66).

On the other hand, the unlisted companies with the highest levels of debt concern the Energy (2.88), Utility (1.70) and Consumer cyclical (1.68) sectors, while the least indebted firms are in the Industrial, Consumer non-cyclical and Telecommunications (1.55), Basic Materials (1.35) and Healthcare (0.95) sectors.

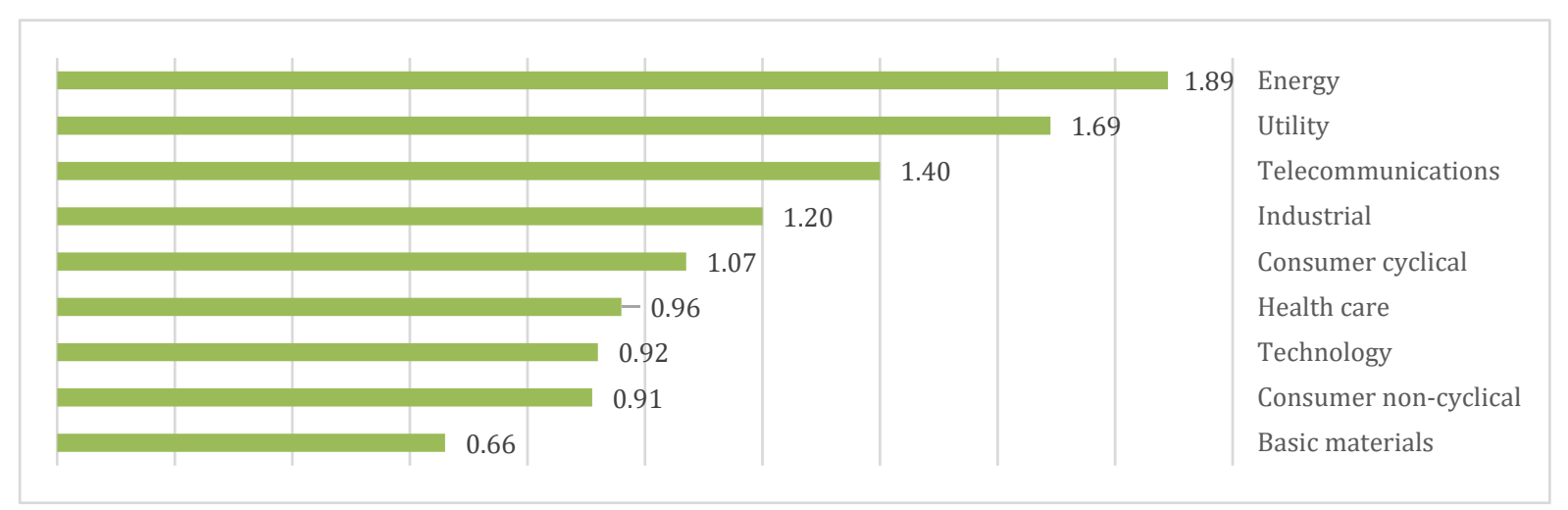

Figure 1. D/E (average values): ranking listed companies (2015-2017) 


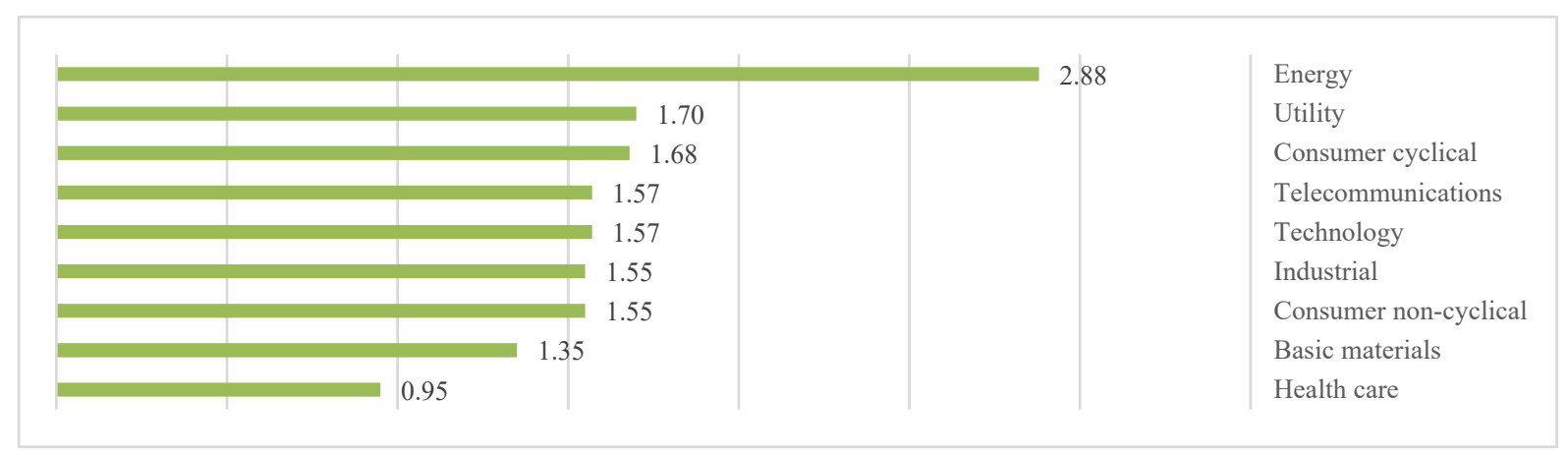

Figure 2. D/E (average values): ranking unlisted companies (2015-2017)

As regards 2015, the most indebted listed companies are in the Energy (2.02), Telecommunications (1.52) and Utility (1.47) sectors, while the least indebted companies are in the Consumer non-cyclical (0.91), Technology (0.87) and Basic Materials (0.64) sectors.

The unlisted companies with the highest debt values are in the Energy (3.12), Technology (1.61) and Consumer cyclical (1.60) sectors and those with the lowest values are in the Basic Materials (1.36), Utility (1.34) and Healthcare (0.98) sectors.

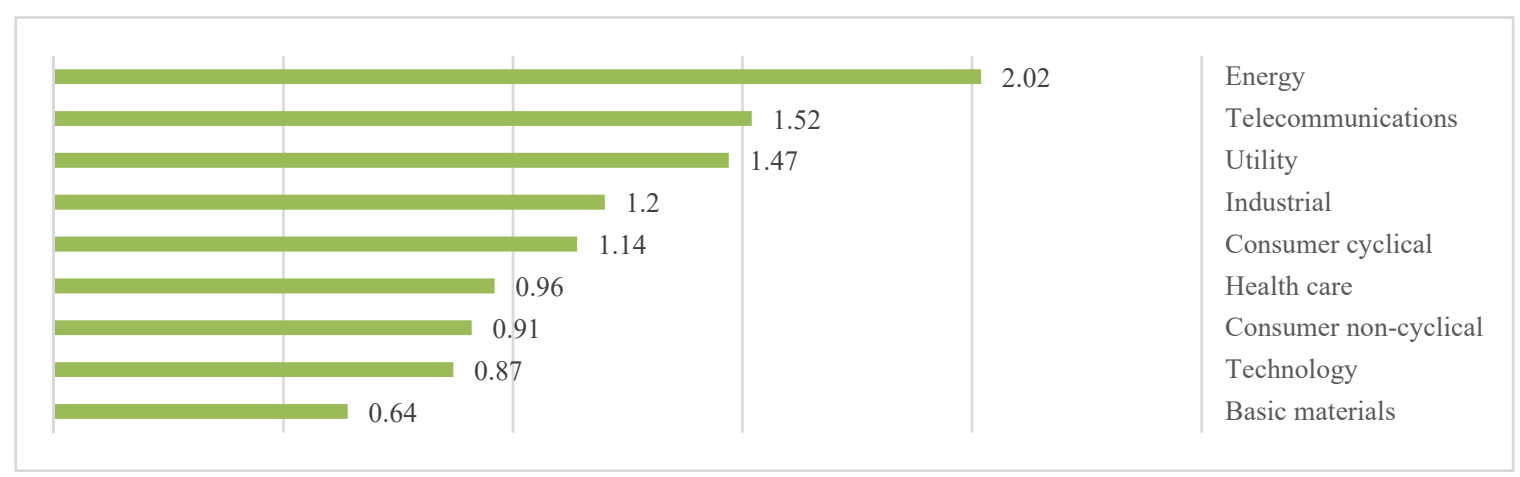

Figure 3. D/E (average values): ranking listed companies (2015)

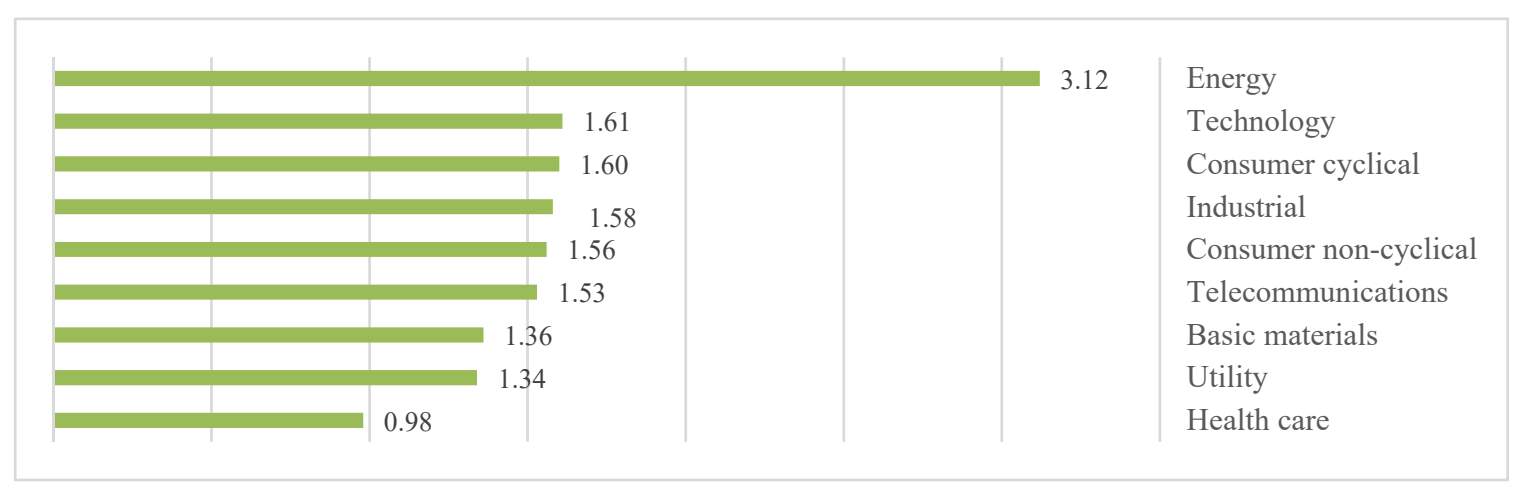

Figure 4. D/E (average values): ranking unlisted companies (2015)

For 2016, the listed companies with the highest leverage values are in the Energy (1.77), Utility (1.71) and Telecommunications (1.34) sectors; the lowest values are in the Technology (0.97) Consumer non-cyclical (0.93) and Basic Materials (0.65) sectors.

For the unlisted, the first D/E values are in the Energy (2.86), Consumer cyclical (1.85) and Industrial (1.58) sectors and the last values correspond to the Utility (1.55), Basic Materials (1.34) and Healthcare (0.96) sectors. 


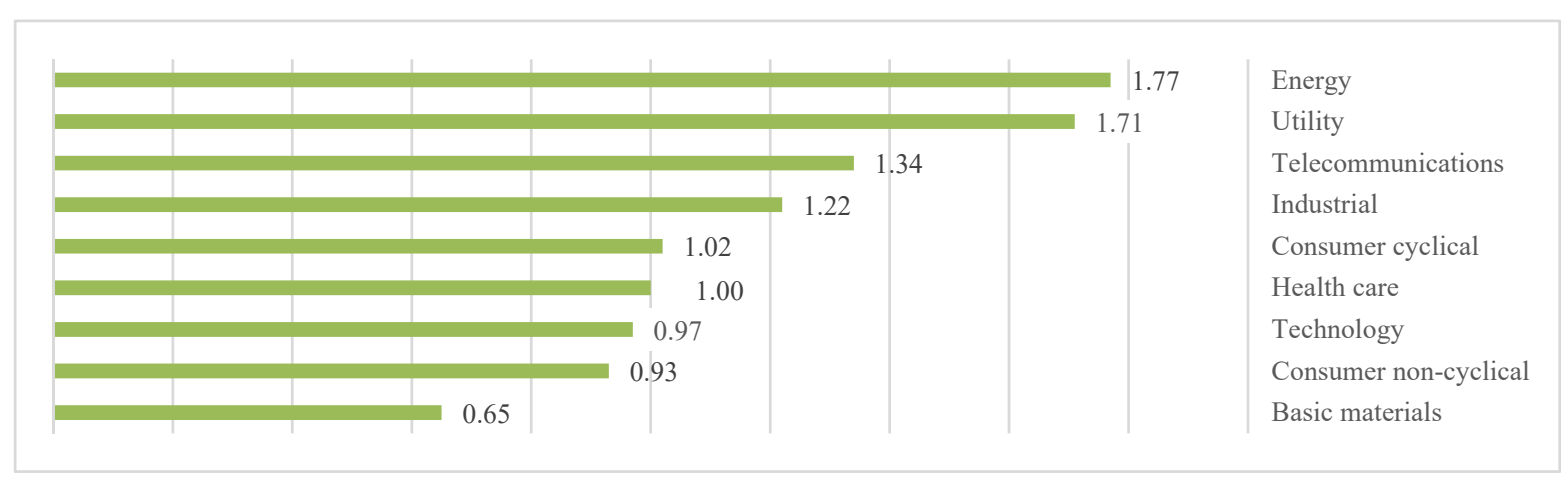

Figure 5. D/E (average values): ranking listed companies (2016)

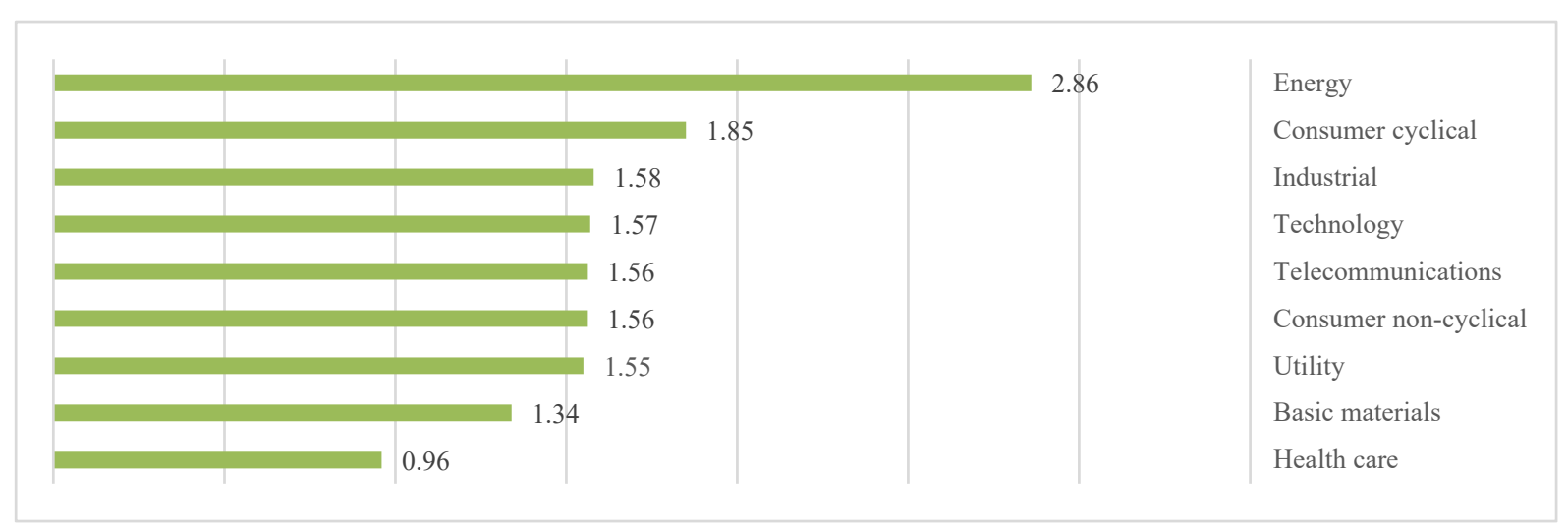

Figure 6. D/E (average values): ranking unlisted companies (2016)

Lastly, for 2017, the higher values of the D/E for the listed companies concern the Utility (1.89), Energy (1.87) and Telecommunications (1.33) sectors, while the last values refer to the Healthcare (0.93), Consumer non-cyclical (0.88) and Basic materials (0.68) sectors.

For unlisted companies, the sectors with the highest debt values are Energy (2.67), Utility (2.22) and Consumer cyclical (1.59), those with the lowest values are Industrial (1.49) Basic materials (1.35) and Healthcare (0.92).

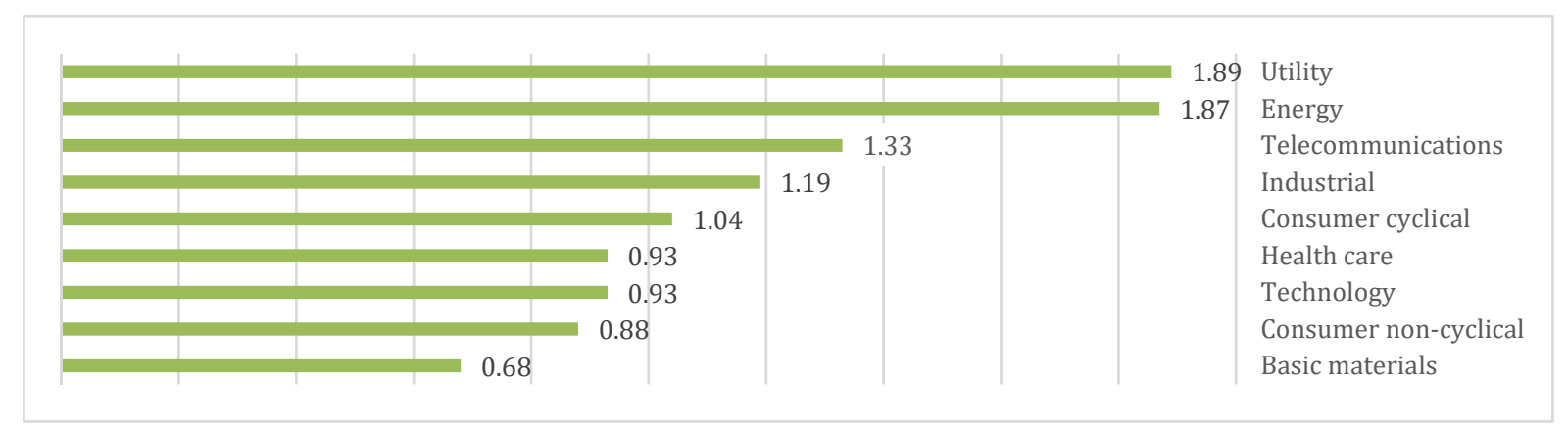

Figure 7. D/E (average values): ranking listed companies (2017) 


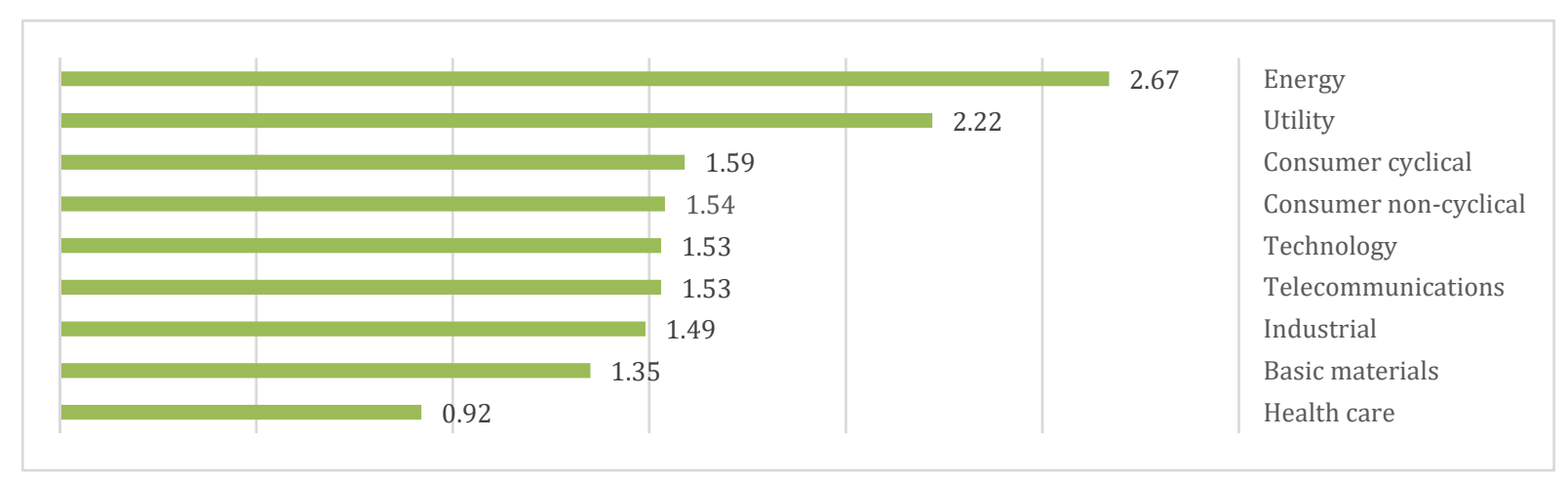

Figure 8. D/E (average values): ranking unlisted companies (2017)

To verify whether the listing influences the financial structure or not, the leverage differences between means for listed and unlisted companies were computed separately for the various sectors. The differences between the means of $\mathrm{D} / \mathrm{E}$ for listed and unlisted were then subjected to t-test in order to check their statistical significance.

Results of the t-test showed that the averages were comparable given the significance of the differences at the $1 \%$ level for all sectors, with the exception of the Health Care, Utility and Telecommunications sector, the latter limited to 2015 .

Table 2. D/E: difference between the means listed vs unlisted companies

\begin{tabular}{lllll}
\hline Sector & $\mathbf{2 0 1 5}$ & $\mathbf{2 0 1 6}$ & $\mathbf{2 0 1 7}$ & $\mathbf{2 0 1 5 - 2 0 1 7}$ \\
\hline Health care & -0.01 & 0.03 & 0.01 & 0.01 \\
& $(0.954)$ & $(0.890)$ & $(0.955)$ & $(0.931)$ \\
Consumer cyclical & $-0.46 * * *$ & $-0.83 * * *$ & $-0.55^{* * *}$ & $-0.61^{* * *}$ \\
& $(0.000)$ & $(0.000)$ & $(0.000)$ & $(0.000)$ \\
Consumer non-cyclical & $-0.66 * * *$ & $-0.63 * * *$ & $-0.66^{* * *}$ & $-0.65^{* * *}$ \\
& $(0.000)$ & $(0.000)$ & $(0.000)$ & $(0.000)$ \\
Energy & $-1.11 * *$ & $-1.09 * * *$ & $-0.79 * *$ & $-1.00^{* * *}$ \\
& $(0.011)$ & $(0.005)$ & $(0.046)$ & $(0.000)$ \\
Industrial & $-0.38 * * *$ & $-0.36 * * *$ & $-0.30 * * *$ & $-0.34^{* * *}$ \\
& $(0.000)$ & $(0.000)$ & $(0.000)$ & $(0.000)$ \\
Basic materials & $-0.72 * * *$ & $-0.69 * * *$ & $-0.67 * * *$ & $-0.70^{* * *}$ \\
& $(0.000)$ & $(0.000)$ & $(0.000)$ & $(0.000)$ \\
Technology & $-0.74 * * *$ & $-0.59 * * *$ & $-0.60 * * *$ & $-0.65^{* * *}$ \\
Telecommunications & $(0.000)$ & $(0.000)$ & $(0.000)$ & $(0.000)$ \\
Utility & 0.00 & $-0.23 *$ & $-0.25 * *$ & $-0.16^{* *}$ \\
& $(0.972)$ & $(0.091)$ & $(0.050)$ & $(0.028)$ \\
\hline
\end{tabular}

Note: significance level at $* 10 \%, * * 5 \%, * * * 1 \%$.

Considering the entire 2015-2017 period, the statistically significant differences between means have a negative sign in all sectors, confirming that the listed have on average a lower leverage than the unlisted. The differences are also more pronounced in the Energy (-1.00), Basic Materials (-0.70) and Consumer non-cyclical (-0.65) sectors. 


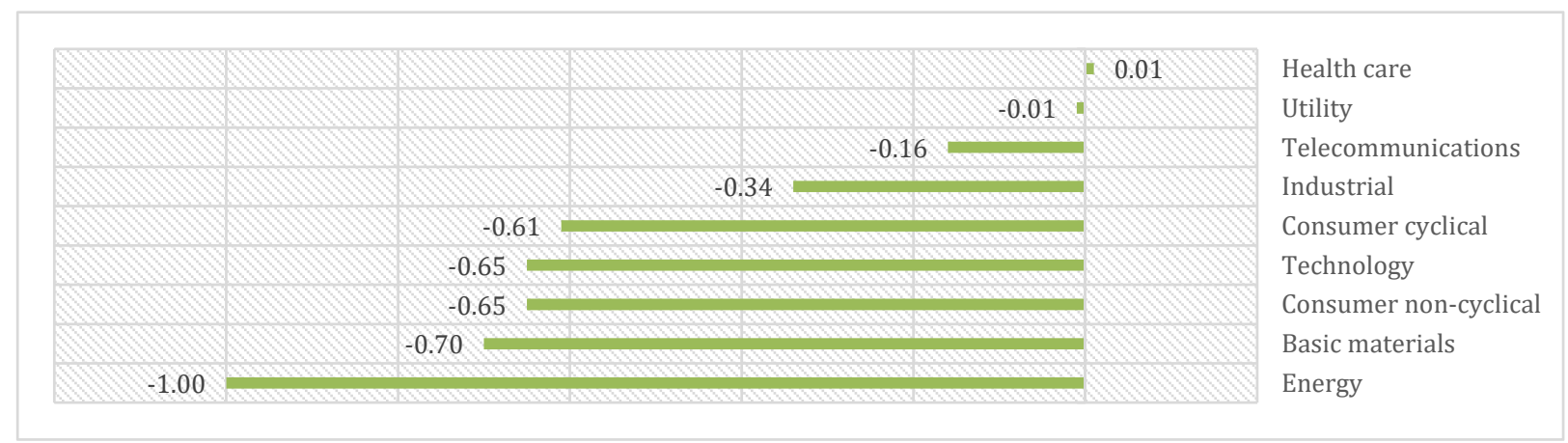

Figure 9. D/E: ranking difference between the means listed vs unlisted companies (2015-2017)

For 2015, the superiority of unlisted companies is confirmed in all sectors, except for Utilities, given a positive $\mathrm{D} / \mathrm{E}$ differential. Sectors with the leverage differential between listed and unlisted most consistent are Energy (1.11), Technology (-0.74) and Basic Materials (-0.72).

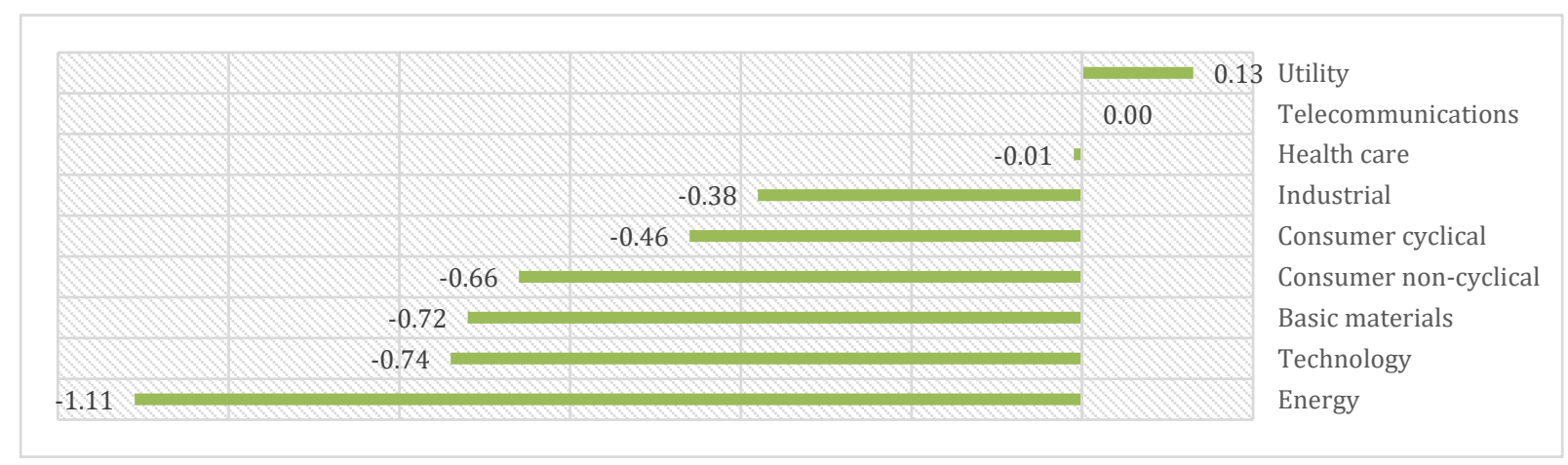

Figure 10. D/E: ranking difference between the means listed vs unlisted companies (2015)

For 2016, in all sectors except Utilities and Healthcare, the D/E values in the listed sample is lower than the unlisted, with more significant differences in the Energy (-1.09), Consumer cyclical $(-0,83)$ and Basic Materials $(-0.69)$.

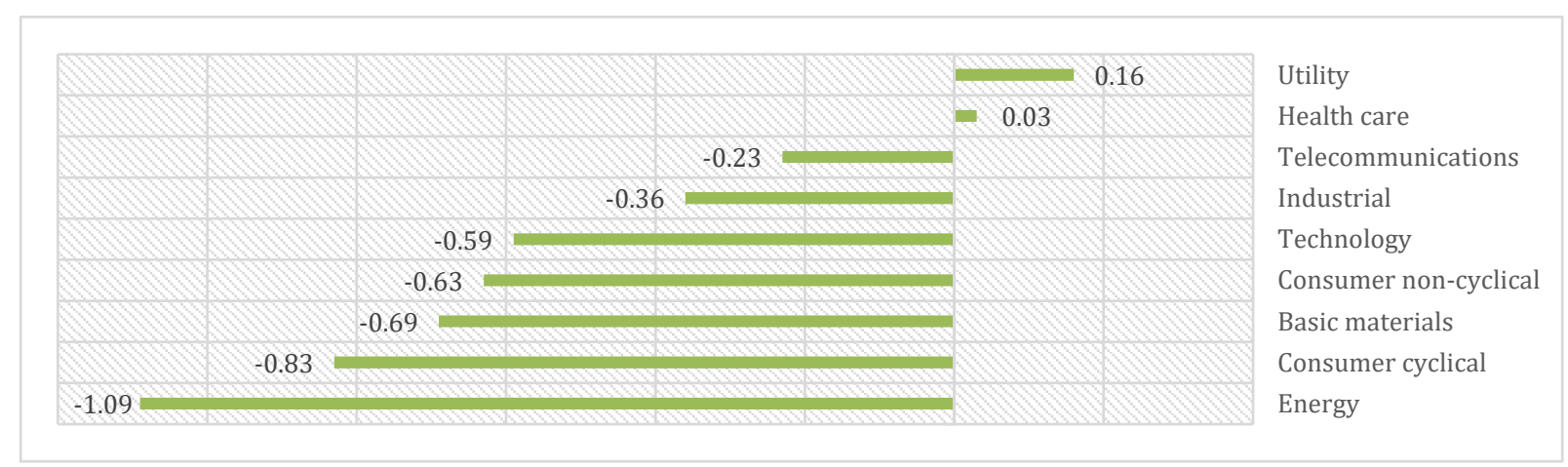

Figure 11. D/E: ranking difference between the means listed vs unlisted companies (2016)

The results are not dissimilar for 2017: with the exception of the Healthcare sector, the unlisted companies have a higher debt than the listed ones, with a greater difference in the Energy $(-0.79)$, Basic materials $(-0.67)$ and Consumer non-cyclical (-0.66). 


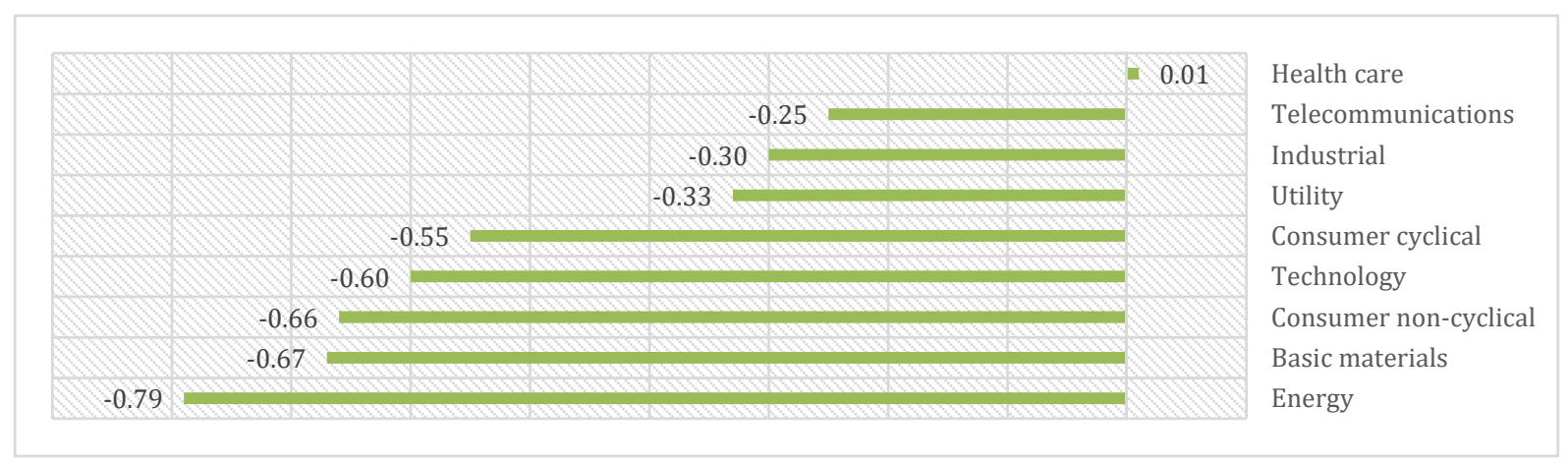

Figure 12. D/E: ranking difference between the means listed vs unlisted companies (2017)

The trend of the financial structure in the 2015-2017 period was therefore observed, separately for the different sectors.

In the Healthcare sector, the D/E of listed companies grew slightly between $2015(0.96)$ and $2016(1.00)$ and then decreased in 2017 (0.93); in unlisted companies it falls between $2015(0.98)$ and $2016(0.96)$ as well as in 2017 (0.92).

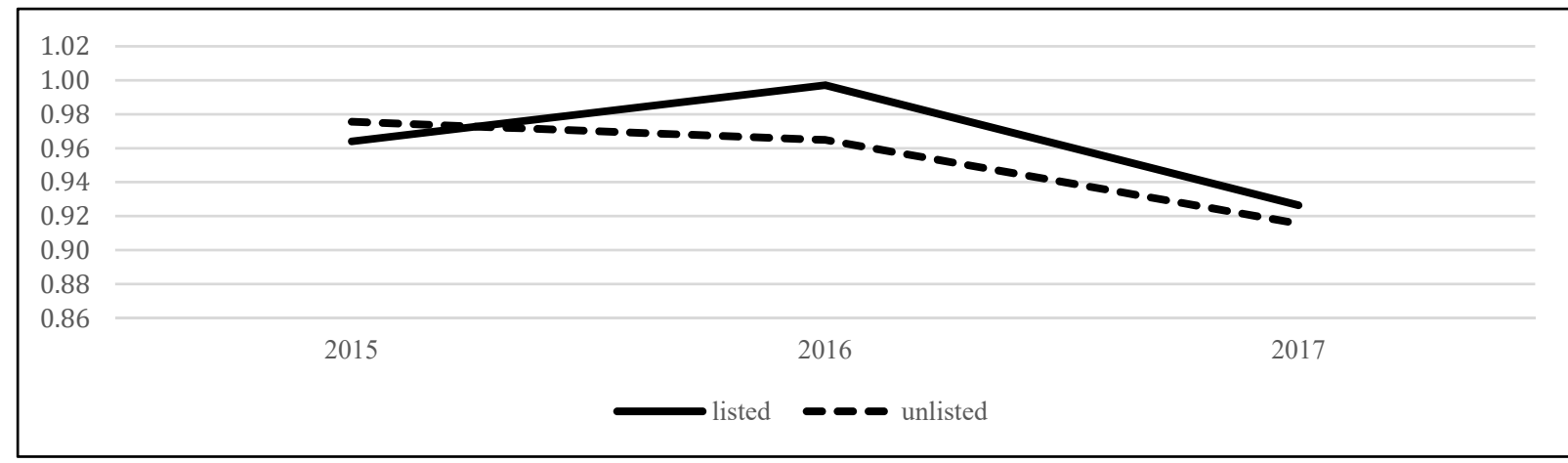

Figure 13. Healthcare: trend D/E (average values) listed vs unlisted companies (2015-2017)

In the Consumer cyclical sector, the debt incidence in listed companies decreases to 1.02 in 2016 from 1.14 in the previous year and, therefore, increases to 1.04 in 2017, as opposed to unlisted companies in which it previously increased from 1.60 to 1.85 in 2016 and then decreases to 1.59 in 2017.

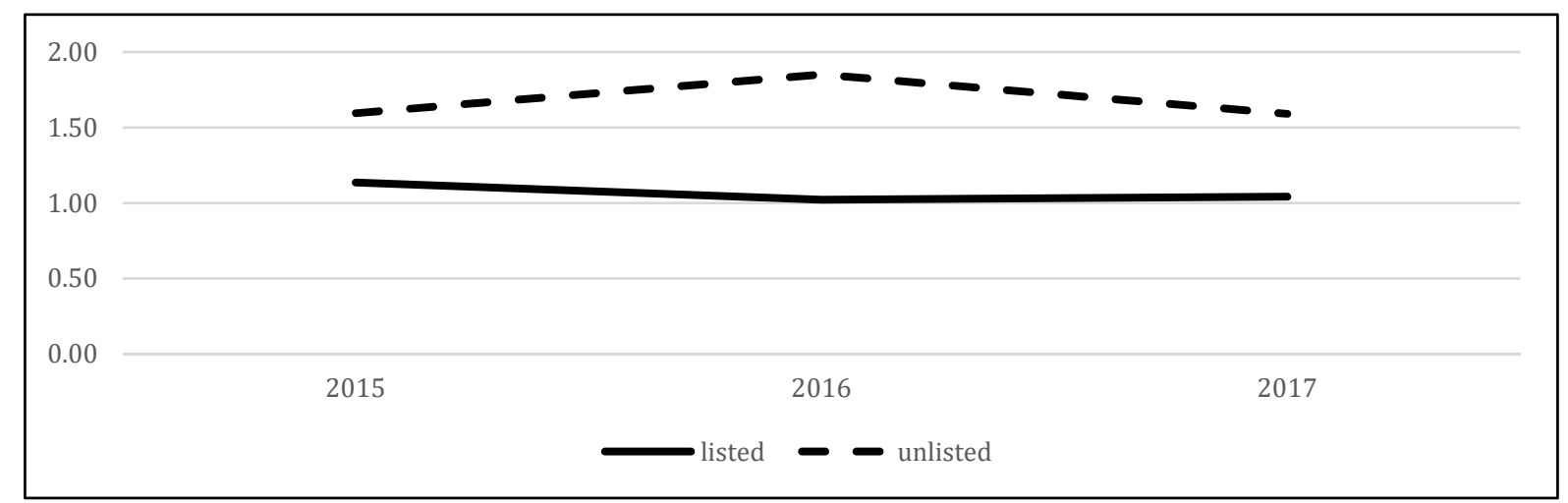

Figure 14. Consumer cyclical: trend D/E (average values) listed vs unlisted companies (2015-2017) 
In the Consumer non-cyclical sector, the $\mathrm{D} / \mathrm{E}$ of listed companies remains substantially stable $(0.91$ in $2015,0.93$ in 2016 and 0.88 in 2017); the same trend is observed for unlisted (1.56 in 2015 and 2016, 1.54 in 2017).

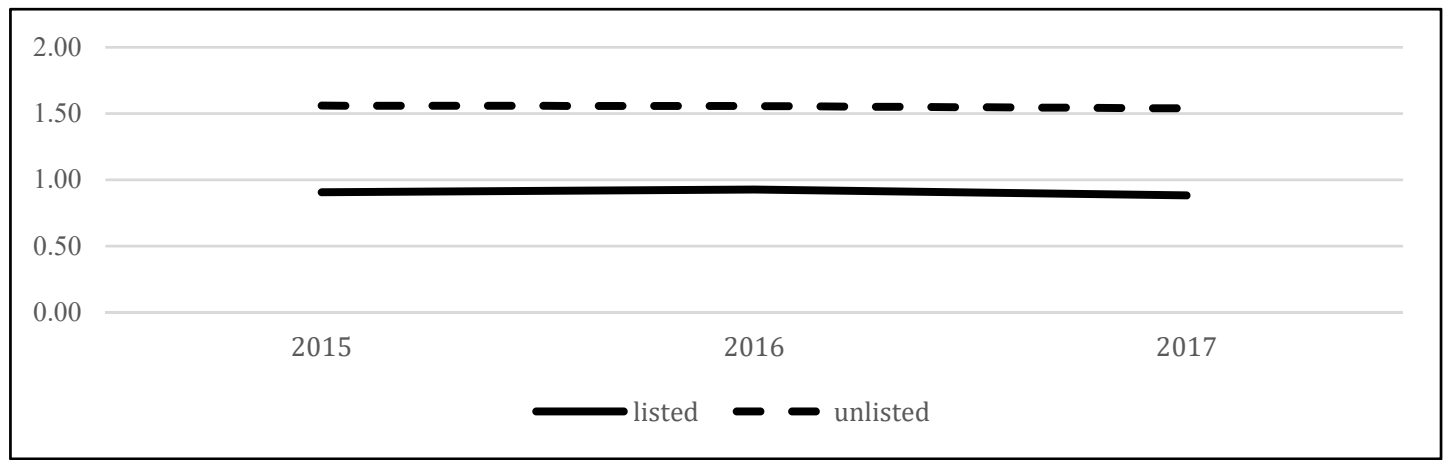

Figure 15. Consumer non-cyclical: trend D/E (average values) listed vs unlisted companies (2015-2017)

In the Energy sector, the $\mathrm{D} / \mathrm{E}$ of the listed companies first decreased from 2.02 to 1.77 in 2016 , then increased to 1.87 in 2017; in the unlisted, it progressively decreased from 3.12 in 2015 to 2.86 in 2016 and then to 2.67 in 2017.

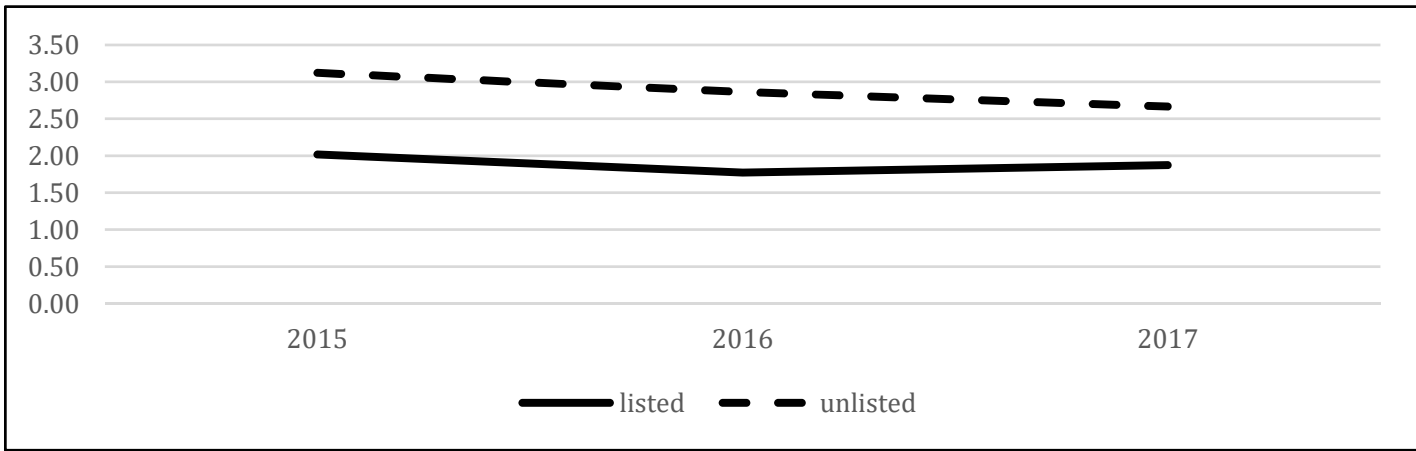

Figure 16. Energy: trend D/E (average values) listed vs unlisted companies (2015-2017)

In the Industry sector, the D/E of listed companies remains substantially stable, going from 1.20 in 2015 to 1.22 in 2017 and 1.19 in 2016, like the unlisted companies where the debt incidence is 1.58 in 2015 and in 2016 and then slightly decreases to 1.49 .

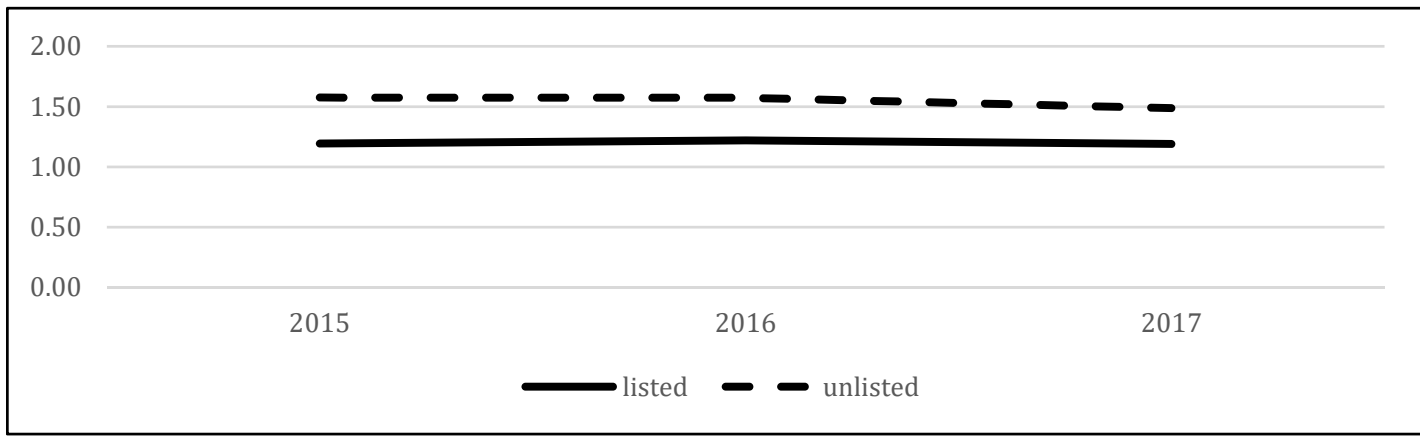

Figure 17. Industry: trend D/E (average values) listed vs unlisted companies (2015-2017)

A similar trend was recorded for the Basic Materials sector: leverage remained substantially stable both in the listed, given the values 0.64 in 2015, 0.65 in 2016 and 0.68 in 2017, and in the unlisted considering the values 1.36 in the $2015,1.34$ in 2016 and 1.35 in 2017. 


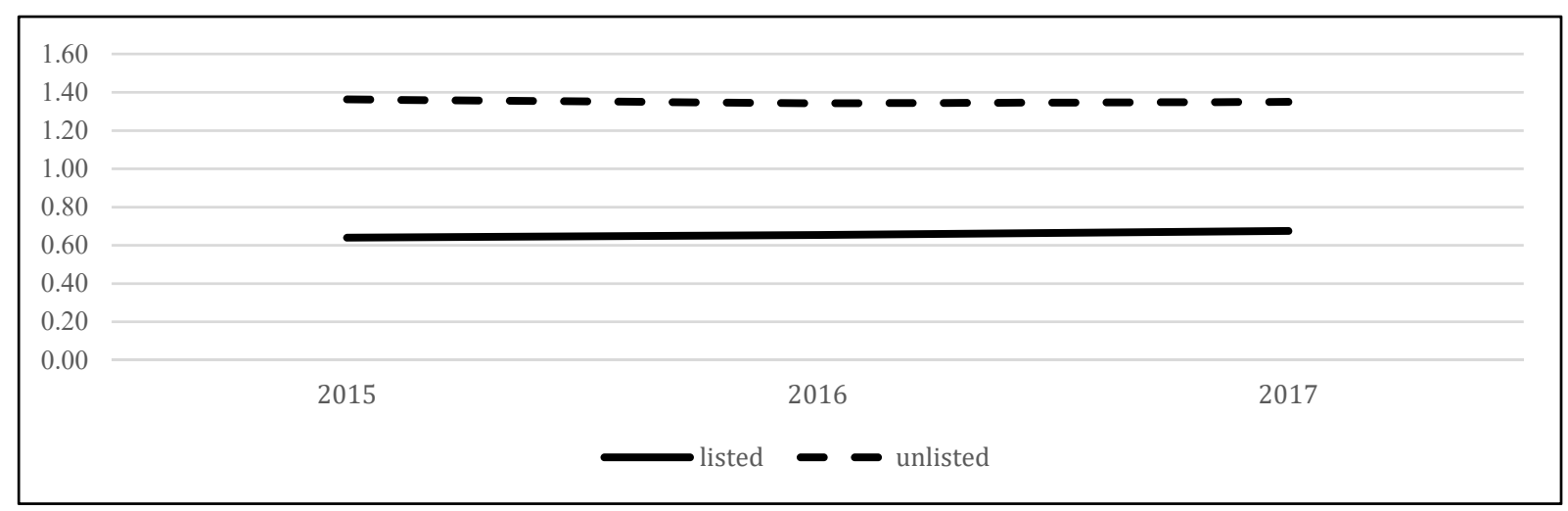

Figure 18. Basic Materials: trend D/E (average values) listed vs unlisted companies (2015-2017)

In the Technology sector, the financial structure of listed companies recorded an increase between $2015(0.87)$ and $2016(0.97)$ as well as a decrease in $2017(0.93)$ while for unlisted companies there was a progressive decrease from 2015 (1.61) to 2016 (1.57) and then to 2017 (1.53).

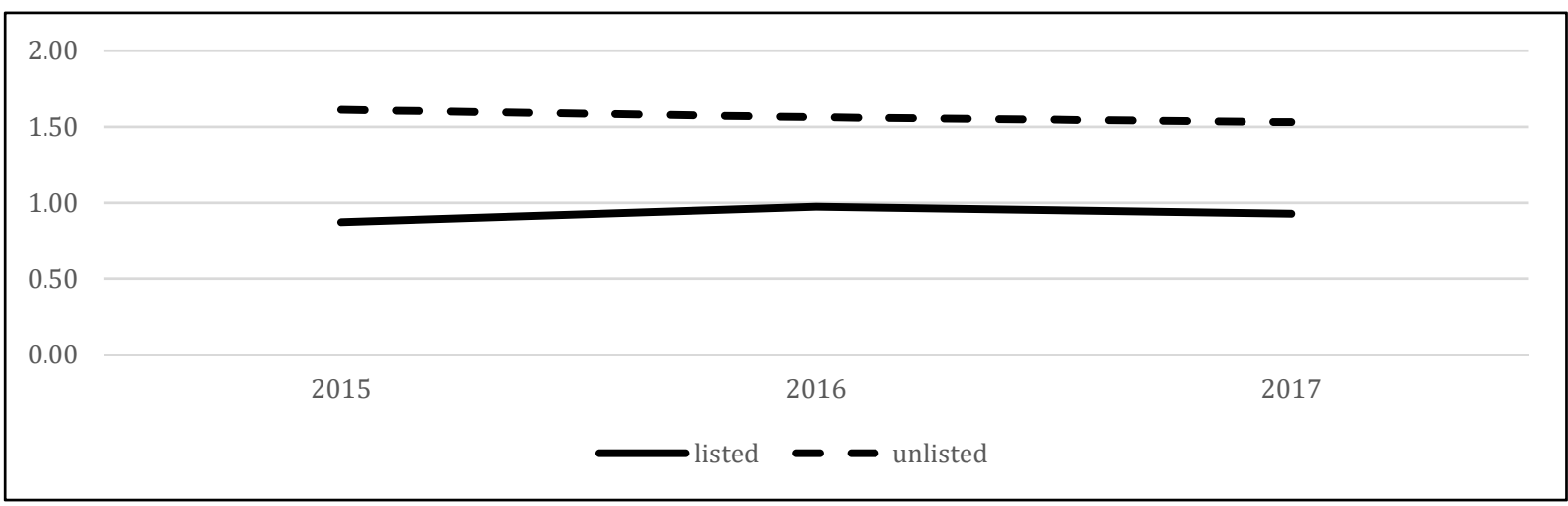

Figure 19. Technology: trend D/E (average values) listed vs unlisted companies (2015-2017)

In the Telecommunications sector, the $\mathrm{D} / \mathrm{E}$ of the listed companies falls from 1.52 to 1.34 in 2016 and further to 1.33 in 2017; for the unlisted ones it is stable in the period, given the values of 1.53 in 2015, 1.56 in 2016 and 1.57 in 2017.

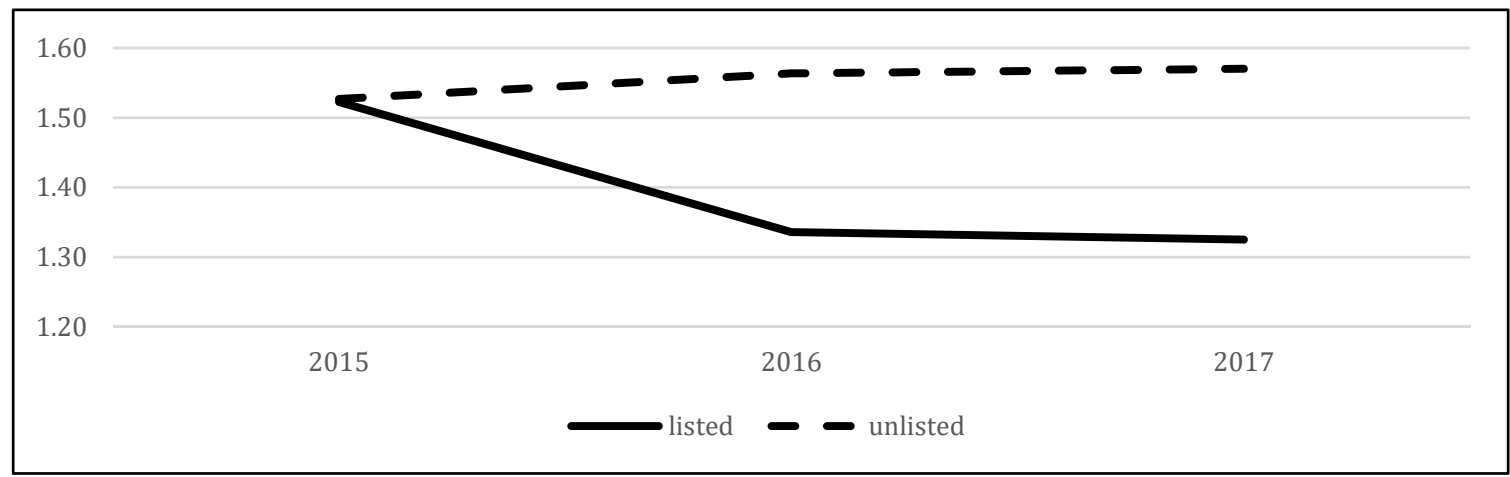

Figure 20. Telecommunications: trend D/E (average values) listed vs unlisted companies (2015-2017)

In the Utility sector, $\mathrm{D} / \mathrm{E}$ grows in both listed and unlisted samples: for the listed companies it progressively 
increases from 1.47 in 2015 to 1.71 in 2016 and to 1.89 in 2017; in the other sample, it improves from 1.34 in 2015 to 1.55 in 2016 and, finally, to 2.22 in 2017.

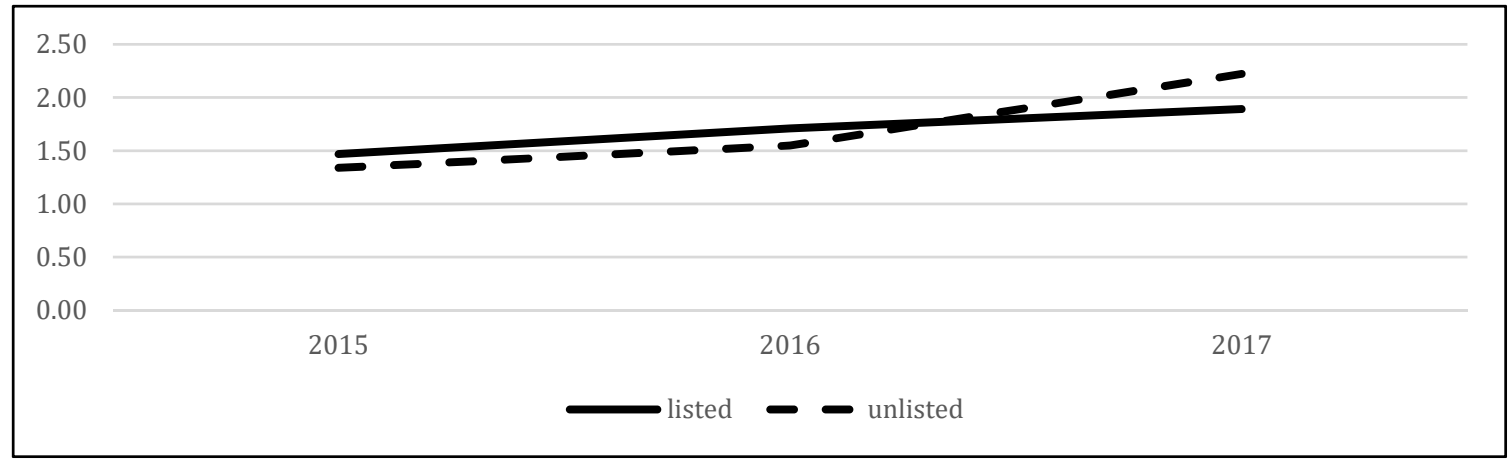

Figure 21. Utility: trend D/E (average values) listed vs unlisted companies (2015-2017)

\section{Conclusions}

Starting the theory of Modigliani \& Miller (1958) the impact of debt-equity ratio on firm value is central topic of corporate finance. Researchers have spent time to develop new thoughts around this theory removing some of the assumptions and hypothesizing others. The paper tests the influence of debt-equity structure on the supposition that the financial structure is the main limit to the maximization of value in SMEs, which is also confirmed by literature. Several authors analyzed financial structure decisions. With regard to debt, the choice between the short and medium-long term is influenced by the benefits and disadvantages associated with financial sources (GarcíaTeruel \& Martínez-Solano, 2007). Short-term debt has generally lower nominal interest rates and is easily adaptable to the financial needs of the firm but it carries a higher level of risk (Jun and Jen; 2003). Considered that, weak firms should prefer long-term debt since the benefits of the short term are not deemed sufficient to compensate for the additional risks (García-Teruel \& Martínez-Solano, 2007). Beyond these general criteria which would determine the decisions on the financial structure, the choices are influenced by several variables, such as the phase of the life cycle, the size, the profitability, the availability of collateral, the ownership structure, the sector to which company belongs and the geographical location (Guiso, 2003; Worthington, 2013).

Light on this, the present survey intends first of all to ascertain whether the listing is really an option to overcome this limit and create, therefore, value, considers the greatest opportunities that can arise from it in terms of supplying equity, or represents a decision that can destroy value, data and costs that it entails. The topic of financial structure recurs frequently in the corporate finance researches since the study of Modigliani and Miller (1958). This study aims to ascertain whether the recourse to debt in listed companies is lower than in unlisted companies. In details, we compared a sample of listed and unlisted European companies grouped in nine sectors (Healthcare, Consumer cyclical, Consumer non-cyclical, Energy, Industrials, Basic materials, Technology, Telecommunications and Utilities) in the period 2015-2017. Financial structure was measured using the debt to equity ratio (D/E). Data regarding the financial structure were extracted from database Amadeus and subjected to deletion of outliers to improve their statistical significance. The average values of $\mathrm{D} / \mathrm{E}$ were computed for each year and for each sector respectively for listed and unlisted samples. So, we calculated the differences between means as "means of D/E for listed companies-means of $\mathrm{D} / \mathrm{E}$ for unlisted companies" and we used the t-test to observe the statistical significance. We found that they were significant at $1 \%$ level (which means that the means values of $\mathrm{D} / \mathrm{E}$ were comparable), for all sectors with the exception of the Health Care, Utility and Telecommunications sector, the latter limited to 2015. Results showed that averages D/E ratio are almost always greater for unlisted companies that means unlisted companies make greater use of debt capital.

Even if the unlisted companies show less variability, there is no precise trend in the listed and unlisted samples, such as to be able to deduce a specific reactivity to market trends. On the other hand, the period under observation was not characterized by particular conditions of the financial market, in terms of credit crunch or negative sentiment towards equity investment, which could have influenced the financial structure of companies. 


\section{References}

Akerlof G. A. (1970). The Market for "Lemons": Quality Uncertainty and the Market Mechanism. The Quarterly Journal of Economics, 84(3), 488-500.

Asker, J., Farre-Mensa, J., \& Ljungqvist, A. (2014). Comparing the Investment Behavior of Public and Private Firms. The Review of Financial Studies, 28(2), 342-390. https://doi.org/10.1093/rfs/hhu077

Ayyagari M., Demirguc-Kunt, A., \& Maksimovic, V. (2005). How important are financing constraints? The role of finance in the business environment. World Bank Mimeo. https://doi.org/10.1093/wber/lhn018

Balakrishnan, S., \& Koza, M. P. (1993). Information asymmetry, adverse selection and joint-ventures: Theory and evidence. Journal of Economic Behavior \& Organization, 20, 99-117. https://doi.org/10.1016/01672681(93)90083-2

Bates, J., \& Hally, D. L. (1982). The Financing of Small Business (3rd ed.). London, Sweet \& Maxwell.

Beck, T., \& Demirguc-Kunt, A. (2006). Small and medium-sized enterprises: Access to finance as a growth constraint. Journal of Banking \& Finance, 30, 2931-2943.

Berger, A. N., \& Udell, G. F. (1998). The Economics of Small Business Finance: The Roles of Private Equity and Debt Markets in the Financial Growth Cycle. Journal of Banking and Finance, 22, 613-673. https://doi.org/10.1016/S0378-4266(98)00038-7Get

Brav, O. (2009). Access to Capital, Capital Structure, and the Funding of the Firm. The Journal of Finance, 64(1), 263-308. https://doi.org/10.1111/j.1540-6261.2008.01434.x

Capasso, A., Rossi, M., \& Simonetti, B. (2005). Ownership Structure Heterogeneity and Performance: A Comparison between Listed and Unlisted Companies. SSRN Electronic Journal.

Carpenter, R. E., \& Petersen, B. C. (2002). Is the growth of small firms constrained by internal finance? The Review of Economics and Statistics, 84(2), 298-309. https://doi.org/10.1007/s10657-005-5276-3

Carpenter, R. E., \& Rondi, L. (2004). Going Public to Grow? Evidence from a Panel of Italian Firms. Ceris-Cnr Working Paper. https://doi.org/10.1023/A:1010989312623

Caselli, S. (2003). PMI e sistema finanziario. Comportamento delle imprese e strategia delle banche. Egea.

Corigliano, R. (2001). Il venture capital. Finanziamento dell'innovazione, capitale di rischio e nuovi mercati finanziari. Bancaria Editrice.

Fama, E. (1980). Agency problems and the theory of the firm. Journal of Political Economy, 88, 288-307.

Fama, E., \& Miller, M. (1972). The theory of finance. Dryden Press.

Gao, H., Harford, J., \& Li, K. (2013). Determinants of Corporate Cash Policy: Insights from Private Firms. Journal of Financial Economics, 109(3), 623-639. https://doi.org/10.1016/j.jfineco.2013.04.008

García-Teruel, P. J., \& Martínez-Solano, P. (2007). Short-Term Debt in Spanish SMEs. International Small Business Journal, 25(6), 579-602. https://doi.org/10.1177/0266242607082523

Global IPO Institutional Investor survey. (2009).

Guiso, A. (2003). Small business finance in Italy. EIB Papers, 8(2), 121-149.

Holtz-Eakin, D., Joulfaian, D., \& Rosen, H. S. (1994). Entrepreneurial Decisions and Liquidity Constraints. The RAND Journal of Economics, 25(2), 334-347. https://doi.org/10.2307/2555834

Hutchinson, P. J., \& Ray, G. H. (1983). The Financing and Financial Control of Small Enterprise Development. Gower Publishing Company Limited, England.

Jensen, M. C., \& Meckling, W. H. (1976). Theory of the firm: Managerial behavior, agency costs and ownership structure. Journal of Financial Economics, 3(4), 305-360.

Jun, S., \& Jen, F. C. (2003). Trade-off model on debt maturity structure. Review of Quantitative Finance and Accounting, 20(1), 5-34.

Keown, A. J., Scott, Jr. D. F., Martin, J. D., \& Petty, J. W. (1985). Basic Financial Management. (3rd ed.). Prentice Hall International Editions, New Jersey.

Kopyakova, A. (2017). Capital structure determinants: the evidence from listed and unlisted Dutch firms.

Leland, H., \& Pyle, D. H. (1977). Informational Asymmetries, Financial Structure, and Financial Intermediation. Journal of Finance, 32(2), 371-387. 
McLaney, E. (2009). Business Finance: Theory and Practice (8th ed.). Prentice Hall, United Kingdom.

Modigliani, F., \& Miller, M. H. (1958). The Cost of Capital, Corporation Finance and the Theory of Investment. American Economic Review, 48, 261-297.

Myers, S. C. (1977). Determinants of Corporate Borrowing. Journal of Financial Economics, 5, 147-175.

Myers, S. C., \& Majluf, N. S. (1984). Corporate financing and investment decisions whenfirms have information that investors do not have. Journal of Financial Economics, 13, 187-221.

Osteryoung, J. S., Newman, D. L., \& Davies, L. G. (1997). Small Firm Finance: An Entrepreneurial Analysis. The Dryden Press, U.S.A.

Ou, C., \& Haynes, G. W. (2006). Acquisition of Additional Equity Capital by Small Firms - Findings from the National Survey of Small Business Finances. Small Business Economics, 27(2), 157-168. https://doi.org/10.1007/s11187-006-0009-8

Pagano, M., Panetta, F., \& Zingales, L. (1998). Why Do Companies Go Public? An Empirical Analysis”, Journal of Finance, 53, 27-64.

Rajan, R. G., \& Zingales, L. (1995). What do We Know about Capital Structure? Some Evidence from International Data. Journal of Finance, 50, 1421-1460.

Rondi, L., Sembenelli, A., \& Zanetti, G. (1994). Is Excess Sensitivity of Investment to Financial Factors Constant across Firms? Evidence from Panel Data on Italian Companies. Journal of Empirical Finance, 1, 365-383.

Ross, S. (1977). The Determination of Financial Structure: The Incentive-Signaling Approach. Bell Journal of Economics, 8(1), 23-40.

Schoubben, F., \& Hulle, C. (2004). The Determinants of Leverage: Differences Between Quoted and Non-quoted Firms. Tijdschrift voor Economie en Management, 69(4), 589-620.

Worthington, A. (2013). Small and Medium-Sized Enterprises Financing: A Review of Literature. International Journal of Business and Management, 8(14), 36-54.

\section{Copyrights}

Copyright for this article is retained by the author(s), with first publication rights granted to the journal.

This is an open-access article distributed under the terms and conditions of the Creative Commons Attribution license (http://creativecommons.org/licenses/by/4.0/). 